Uluslararası Mühendislik

Cilt/Volume:12 Sayı/Issue:1 Ocak/January 2020

\title{
Karbon Nanotüp takviyeli ZA-27 Esaslı Kompozitlerde Karbon Nanotüp Takviye Oranının Mikroyapı Ve Bazı Mekanik Özelliklere Etkisi
}

\section{Effect of Carbon Nanotube Reinforcement Ratio on Microstructure and Some Mechanical Properties in ZA-27 Based Composites Reinforced with Carbon Nanotube}

\author{
Muharrem Pul iD \\ Kırıkkale Üniversitesi,Kırıkkale Meslek Yüksekokulu, Elektrik ve Enerji Bölümü, 71450, Kırıkkale, TÜRKIYYE
}

Başvuru/Received: 04/11/2019

Kabul / Accepted: 11/01/2020

Çevrimiçi Basım / Published Online: 13/01/2020

Son Versiyon/Final Version: 31/01/2020

\begin{abstract}
$\ddot{O} z$
Son yıllarda kullanılmakta olan mevcut mühendislik malzemeleri gelişen teknolojinin ihtiyaçları karşısında yetersiz kalmaktadır. $\mathrm{Bu}$ sorunu çözmek için daha üstün niteliklerde malzeme araştırmaları gelişerek kompozit malzemeler ortaya çıkmıştır. Kompozitlerin en önemli özelliği hafif, uzun ömürlü ve yüksek dayanımlı malzemeler olmasıdır. Bu üstün özelliklerinden dolayı tüm endüstri alanlarında yaygın olarak kullanılmaktadırlar. Son zamanlarda bu kompozit malzemelerin arasına, nano katkılı daha üstün özellikteki kompozitler katılmıştır. Bu çalışmada çok duvarlı karbon nanotüp (MWCNT) katkılı, ZA-27 (çinkoalüminyum) esaslı nano kompozitler toz metalurjisi yöntemiyle üretilmiştir. ZA-27 alaşımı içerisine farklı oranlarda (\%0,5 $\% 1,0$ - \%1,5 - \%3,0) MWCNT takviye edilmiştir. Üretilen ZA-27 nano katkılı kompozitlerin, taramalı elektron mikroskobunda (SEM) mikroyapıları incelenmiştir. Bazı mekanik özellikleri tespit etmek üzere; yoğunlukları ölçülerek sertlik ve çapraz kırılma deneyleri yapılmıştır. Deneyler sonucunda elde edilen verilere göre nano kompozit malzemelerin içerisindeki nano takviye miktarlarının, kompozitin mekanik özellikleri üzerindeki etkisi değerlendirilmiştir.
\end{abstract}

Anahtar Kelimeler

ZA-27, Karbon Nanolotüp, Mikroyapı, Sertlik, Capraz Kırılma

\begin{abstract}
Classical engineering materials used in recent years are inadequate against the needs of developing technology. In order to solve this problem, advanced material researches were developed and composite materials emerged. The most important feature of composites is that they are light, long lasting and high strength materials. Because of these superior properties, they are widely used in all industrial areas. Recently, among these composite materials, more nano-doped composites have been added. In this study, multi-walled carbon nanotube (MWCNT) doped, ZA-27 (zinc-aluminum) based nano composites were produced by powder metallurgy method. ZA-27 alloy in different proportions $(0.5 \%-1.0 \%-1.5 \%-3.0 \%)$ MWCNT are reinforced. The microstructures of the produced ZA-27 nano doped composites were investigated under scanning electron microscope (SEM). In order to determine some mechanical properties; density and hardness and cross fracture tests were performed. According to the data obtained from the experiments, the effect of the amount of nano-reinforcements in the nano-composite materials on the mechanical properties of the composite was evaluated.
\end{abstract}

Key Words

ZA-27, Carbon Nanotube, Microscructre, Hardness, Transverse Rupture 


\section{Giriş}

Son yıllarda tüm endüstri alanlarında kompozit malzemelerin kullanımı giderek artış göstermektedir. Bu kompozit malzemelerin bir çeşidi olan metal matrisli kompozitler (MMK) üzerine yapılan araştırmalar da giderek yoğunlaşmaktadır. Yapılan çalışmalarda ağırlıklı olarak hafif metal esaslı alüminyum, magnezyum alaşımları çoğunluğu oluşturmaktadır. Ancak, son zamanlarda çinko matrisli seramik takviyeli kompozitlerin üretimi ve özelliklerinin incelenmesi birçok araştırmacı tarafından ilgi duyulan bir çalışma alanı olmuştur. Çinko esaslı alaşımlar ergime sıcaklıklarının düşük olması ve ucuz olmaları nedeniyle matris malzemesi olarak oldukça kullanışlıdırlar. Ayrıca bu alaşımlar mükemmel tribolojik özelliklere sahiptirler. Matris malzemesi olarak kullanılan çinko esaslı alaşımlar arasında, ZA-27 alaşımı oldukça popülerdir (Çelebi ve ark. 2015). ZA-27, çinkoalüminyum alaşımı seri üretime uygunluğu, yüksek korozyon direnci, düşük erime sıcaklığı ve gösterdiği üstün işlenebilme özellikleri sebebiyle başta otomotiv, yapı sektörü olmak üzere, spor malzemeleri, oyuncak, hırdavat, dekorasyon, beyaz eşya vb. alanlarda yaygın olarak kullanılmaktadır. ZA-27 alaşımının diğer bir adı da ZAMAK'tır. ZA-27 alaşımı, MMK malzemelerin geliştirilmesinde esas malzeme olarak kullanılmakta ve bu kullanım sahası her geçen gün büyümektedir. Kompozit malzemelerin özelliklerinin geliştirilmesinde esas malzeme kadar takviye elemanı da etkilidir. Takviye elemanı, kompozit üzerine gelen yükün büyük bir bölümünü taşımaktadır. Bu tür kompozitlerin üretilmesinde kullanılan takviye elemanları içerisinde nano malzemeler giderek yaygınlaşmaktadır. Bu malzemeler içerisinde nano boyuta $\mathrm{B}_{4} \mathrm{C}, \mathrm{SiC}, \mathrm{SiO}_{2}, \mathrm{Al}_{2} \mathrm{O}_{3}, \mathrm{MgO}$, TiB 2 , TiC, karbon nano tüpler (CNT) ve nano grafen (GNP) gibi malzemeler ön plana çıkmaktadır. Günümüzde daha ekonomik, daha hafif ve gelişmiş mekanik özellikler sağlayan bu tür kompozitler üzerine yapılan araştırmalar hız kazanmıştır. Karbon nanotüpler (CNT), 1990’lı yılların başındaki keşiflerinden sonra olağanüstü özelliklerinin fark edilmesi ile yoğun biçimde araştırılmaya başlanmış ve ilerleyen zamanla bu ilgi, söz konusu malzemenin özellikle nanobilim olmak üzere birçok farklı sahada bir "fenomene"e dönüşmesine yol açmıştır. Hem uygulamalı hem de kuramsal birçok çalışmada karbon nanotüpler, nanoteknoloji için bir "model sistem" olmuştur (Pul 2019). Karbon alanında yapılan araştırmalar, 1991'de Iijima tarafından karbon nanotüpleri (CNT) keşfi ile devrim yaratmıştır. Deneyler ve simülasyonlar CNT'lerin karbon elyaflarına göre olağanüstü mekanik özelliklere sahiptir. CNT'lerin $1000 \mathrm{GPa} y a$ kadar sertlik, $100 \mathrm{GPa}$ 'lık mukavemet ve $6000 \mathrm{~W} \mathrm{~m}^{-1} \mathrm{~K}^{-1}$ kadar isıl iletkenlik değerlerine sahip olduğu görülmüştür. Bu araştırmalar, CNT'lerin, insanlığın bildiği, olağanüstü özelliklere sahip en güçlü elyaf olduğunu göstermektedir (Bakshi ve ark. 2010).

Metal matrisli kompozitler alanında yapılan çalışmalarda genellikle alüminyum esaslı nano kompozit çalışmaları oldukça fazla sayıda yapılmıştır. Ancak çinko esaslı bir alaşım olan ZA-27 esaslı nano kompozitler üzerine yeterince yerli ve yabancı çalışma literatürde yer almamaktadır. Bu çalışmada toz metalurjisi yöntemi ile ZA-27 alaşımı içerisine farklı oranlarda MWCNT takviye edilerek nano kompozitler üretilmiştir. Üretilen kompozitlerin mikroyapıları incelenerek yoğunlukları ölçülmüştür. Ayrıca bazı mekanik özelliklerini belirlemek üzere sertlik ölçümleri ve çapraz kırılma deneyleri yapılmıştır. Deney ve ölçmelerden elde edilen veriler mikroyapı görüntüleri ile birlikte değerlendirilmiştir. Bu çalışma ile ZA-27 alaşımının mekanik özellikleri üzerine, farklı miktarlardaki nano grafen katkısının etkileri ve bu katkı miktarlarının optimizasyonu amaçlanmıştır.

\section{Materyal Ve Yöntem}

Bu çalışmada esas malzeme (matris malzemesi) olarak seçilen ZA-27 (çinko-alüminyum) alaşımına ait teknik özellikler Tablo 1 'te verilmektedir.

Tablo 1. ZA-27 alașımının teknik özellikleri

\begin{tabular}{|c|c|c|c|c|c|}
\hline$\% \mathrm{Al}$ & $\% \mathrm{Mg}$ & $\% \mathrm{Cu}$ & $\% \mathrm{Fe}$ & $\% \mathbf{P b}$ & $\% \mathrm{Zn}$ \\
\hline $25,5-28,0$ & $0,01-0,02$ & $2,0-2,5$ & 0,075 & 0,006 & Kalan \\
\hline $\begin{array}{l}\text { Yoğunluk } \\
\text { g/cm }\end{array}$ & $\begin{array}{c}\text { Erime Noktası } \\
{ }^{\circ} \mathrm{C}\end{array}$ & $\begin{array}{l}\text { Sertlik } \\
\text { Brinell }\end{array}$ & $\begin{array}{c}\text { Çekme Dayn. } \\
\text { MPa }\end{array}$ & $\begin{array}{l}\text { Isıl İletkenlik } \\
\text { W/mK }\end{array}$ & $\begin{array}{l}\text { Elekt. İletk. } \\
\mathrm{S} / \mathrm{m}\end{array}$ \\
\hline 5,0 & $376-484$ & $105-125$ & 421 & 123 & 1,72 \\
\hline
\end{tabular}

Kompozitlerin hazırlanmasında takviye elemanı olarak kullanılan çok duvarlı karbon nanotüpe (MWCNT) ait bazı teknik özellikler ve SEM görüntüsü Tablo 2'de verilmiştir.

Tablo 2. MWCNT teknik özellikleri

\begin{tabular}{|c|c|c|c|c|c|c|c|}
\hline Saflık, \% & Dış çap, $\mathbf{n m}$ & İç çap, $\mathbf{n m}$ & Uzunluk, $\boldsymbol{\mu m}$ & Renk & Elektrik İlet., S/m & Isıl ilet., W/mK & SSA, $\mathbf{~ m}^{\mathbf{2}} / \mathbf{g}$ \\
\hline 92 & $8-10$ & $5-8$ & $1-3$ & Siyah & 9800 & $3,0 \times 10^{3}$ & 240 \\
\hline
\end{tabular}

Ağırlıkça \%0,5 - \%1,0 - \%1,5 ve \%3,0 MWCNT olmak üzere dört farklı oranda nano malzeme katkılı ZA-27 nano kompozitin üretilmesi planlanmıştır. Kompozitlerin hazırlanmasında ilk aşamada, hesaplanan ağırlık oranlarındaki ZA-27 ve MWCNT nano malzemeler bilyalı değirmende 90 min süreyle $450 \mathrm{rpm}$ devirle karıştırılarak homojen bir karışım elde edilmiştir. Karıştırma işlemi sırasında $8 \mathrm{~mm}$ çaplı çelik bilyeler kullanılmıştır. Karıştırmadaki malzeme/bilye ağırlık oranı 5/1 olarak seçilmiştir. Presleme sonrasında ve nano kompozit numunelerin kalıptan rahat çıkabilmesi için kaymayı artırmak ve sürtünmeyi azaltmak amacıyla karışım içerisine \% 0,5 oranında yalayıcı özelliği olan Çinko Stearat ilave edilmiştir. Karıştırma işleminden sonra elde edilen kompozit karışımlar ayrı ayrı işaretlenerek sıkıştırma işlemine hazır hale gelmiştir. Dört farklı takviye miktarına göre hazırlanan ZA-27+MWCNT toz karışımlar çelik kalıp içerisinde $500 \mathrm{MPa}$ basınç altında hidrolik preste sıkıştırılmıştır. 
Sıkıştırma işlemi tamamlanan nano kompozit numuneler, ısıl işlem firınında sinterleme 1sıl işlemine işlemine tabi tutulmuşlardır. Sinterleme işleminde, firın sıcaklığı, $40-45$ dakikada kademeli olarak $400^{\circ} \mathrm{C}, 425^{\circ} \mathrm{C}$ ve $450^{\circ} \mathrm{C}$ 'lere çıkartılmış ve bu sıcaklıklarda 90 dakika boyunca sinterleme yapılarak sinterleme işlemleri tamamlanmıştır. Daha sonra 1sıl işlem firını kendi halinde soğumaya bırakılarak soğuyan nano kompozit numuneler firın içerisinden alınmıştır. Şekil 1'deki fotoğrafta sinterleme işlemi tamamlanan kompozit numunelere ait görüntü verilmiştir.

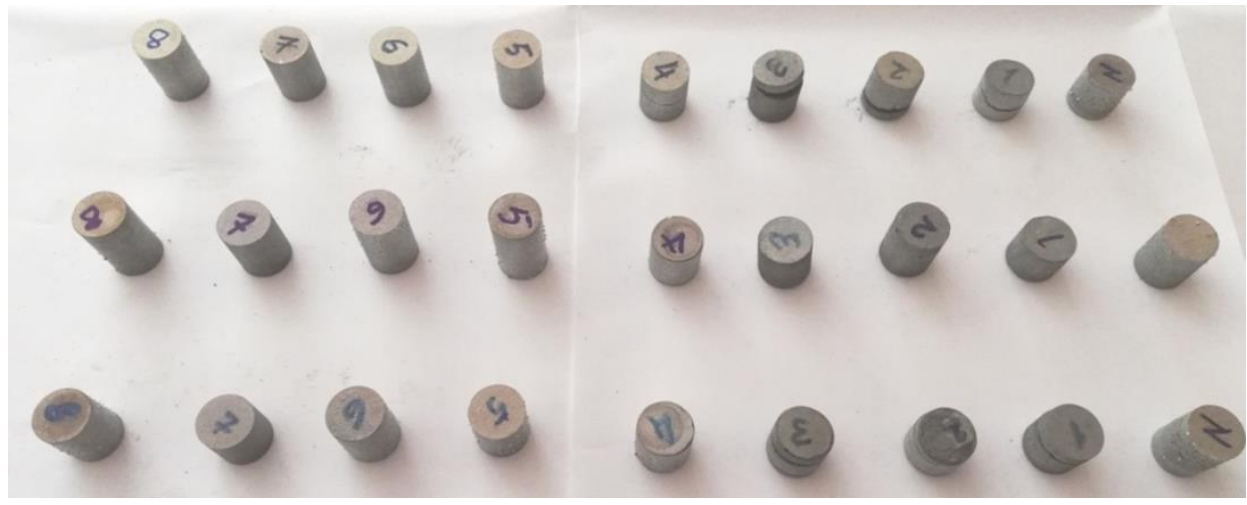

Şekil 1. Sinterleme işlemi tamamlanmış nano kompozit numuneler

Sinterleme işleminden sonra nano kompozit malzemelerin üretim süreci tamamlanarak mikroyapı incelemeleri ve mekanik deneyler aşamasına geçilmiştir. İlk olarak kompozit numunelerin mikroyapılarını incelemek amacıyla yüzey hazırlama işlemi yapılmıştır. Yüzey hazırlama işleminde sırasıyla 400, 800 ve 1200 mesh zımparalama işlemi yapılmış ve son olarak 3 mikronluk $\mathrm{Al}_{2} \mathrm{O}_{3}$ sıvı solüsyon kullanılarak parlatma çuhası ile yüzeyler hazırlanmıştır. Son olarak parlatılmış yüzeyler etil alkol ile yıkanarak yüzey hazırlama işlemleri tamamlanmıştır. Kompozit numunelerin mikroyapı görüntüleri, SEM mikroskobu vasıtasıyla çekilmiştir. Daha sonra üretilen nano takviyeli kompozit numunelerin gözenek oranını belirleyebilmek amacıyla arşimet prensibine göre yoğunluk ölçümleri yapılmıştır. Mekanik deneylerin ilk aşamasında nano kompozitlerin sertlik ölçümleri yapılmıştır. Sertlik ölçümleri Brinell yöntemine göre $15,625 \mathrm{~kg}$ yükleme ile $2,5 \mathrm{~mm}$ 'lik ölçme probuyla mikro sertlik ölçme cihazında yapılmıştır. Sertlik ölçümlerinde, her takviye oranına ait bir adet numune üzerinde 5 farklı noktadan ölçüm yapılarak ortalama değer hesaplanmıştır. Mekanik deneylerin ikinci aşamasında çapraz kırılma (üç nokta eğme) deneyleri yapılmıştır. Deneyler $0,05 \mathrm{kN} / \mathrm{sn}$ yükleme hızıyla 5 ton kapasiteli hidrolik eğme presinde gerçekleştirilmiştir. Çapraz kırılma deneyleri ve ASTM-B 528-05 (2008) standardına uygun olarak, her takviye hacim oranı için üçer adet yapılarak ortalama değer hesaplanmiştır.

Yapılan tüm deney ve ölçmelerden elde edilen sonuçlar değerlendirilerek, nano kompozit numunelerin bazı mekanik özellikleri incelenerek, ZA-27 alaşımı içerisindeki nano malzeme katkı oranlarının optimum miktarlarının belirlenmesine çalışılmıştır. Ayrıca, katkısız ticari ZA-27 malzeme ile karşılaştırılarak, MWCNT nano malzemelerinin katkısının ZA-27 alaşımına kazandırdığı özellikler yorumlanmıştır. Metin içerisinde bundan sonra MWCNT ifadesi yerine CNT kısaltması kullanılmıştır.

\section{Sonuçlar ve Tartışma}

\subsection{CNT Takviye Oranlarına Göre Mikroyapıların Değerlendirilmesi}

CNT takviyeli ZA-27 matrisli kompozitlerin, takviye oranlarına göre mikroyapılarını değerlendirmek amacıyla çekilmiş elektron mikroskobu (SEM) görüntüleri Şekil 2'de verilmiştir.
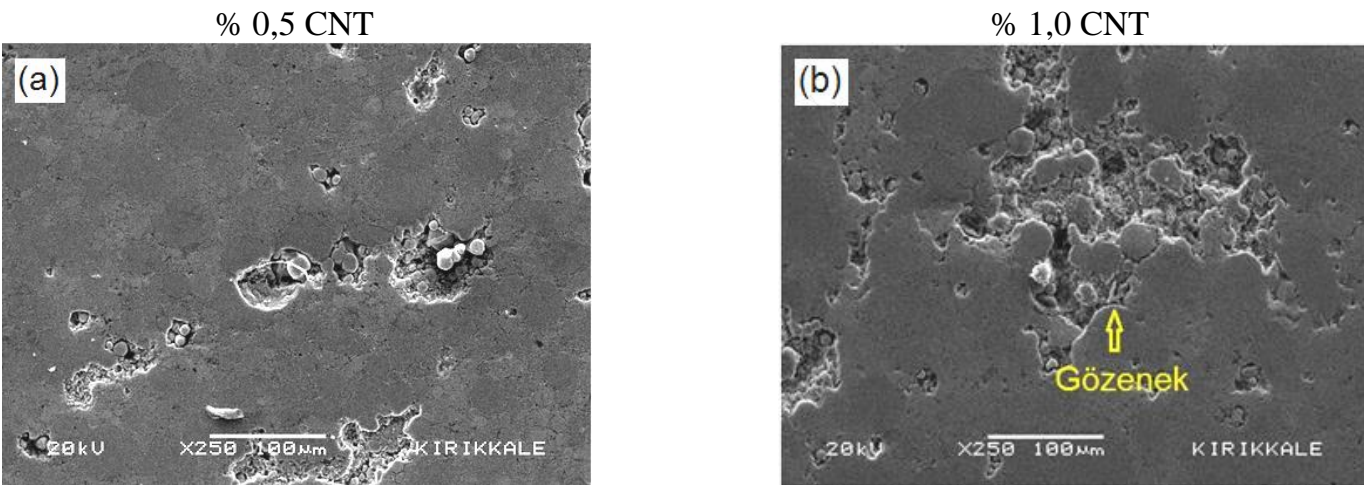

Şekil 2. CNT takviye oranlarına göre, $\times 250$ büyütmede kompozit mikroyapılar 
$\% 1,5 \mathrm{CNT}$

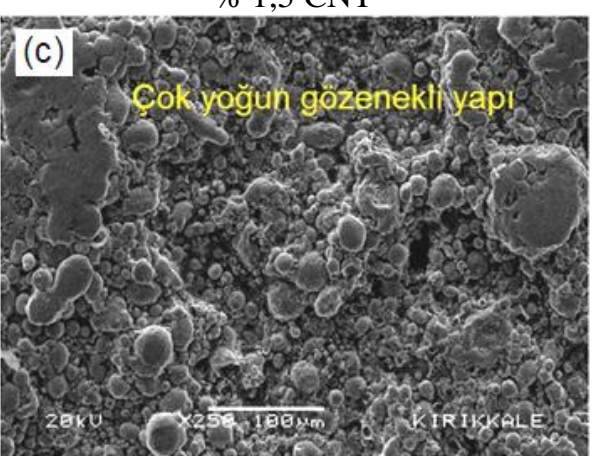

$\%$ 3,0 CNT

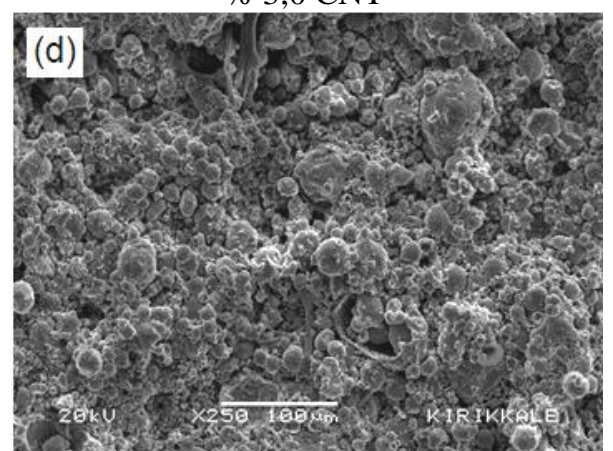

Şekil 2(devam). CNT takviye oranlarına göre, $\times 250$ büyütmede kompozit mikroyapılar

Şekil 2'deki görüntülere topluca bakıldığında ilk göze çarpan tüm numunelerde gözenekli mikroyapının oluşmasıdır. CNT takviye oranının artışına bağlı olarak gözenek oranlarının artış gösterdiği görünmektedir Şekil 2 (c) ve (d). CNT miktarının artmasıyla, mikroyapıdaki homojen dağılım ve ZA-27 tanecikleri arasındaki bağ oluşumu olumsuz etkilenmiştir. Sinterleme işlemiyle biribirine bağlanamayan ZA-27 tanecikleri arasında topaklanma eğilimi ortaya çıkmıştır. Kompozit karışımların hazırlanmasında; döner tamburlu karıştırıcı kullanılarak, 300 rpm hızda 120 dakika süre ile ZA-27 tozları ile takviye malzemesi nano CNT parçacıkları karıştırma işlemine tabi tutulmuştur. Elde edilen mikroyapılara bakıldığında, yapılan karıştırma işleminin yöntemi, süresi ve hızının tam anlamıyla yeterli olamadığı söylenebilir. Bu tür nano malzeme katkılı kompozit yapıların elde edilmesinde ultrasonik veya manyetik karıştırma işlemlerinin uygulanarak mikroyapı sonuçlarının karşılaştırılması ve mekanik yöntemle yapılan karıştırmaya göre mukayese edilmesi tavsiye edilebilir.

Nano katkısız ZA-27 numuneler preste sıkıştırma işleminden sonra ergime derecesi dikkate alınarak, $400^{\circ} \mathrm{C}$ 'de ve diğer kompozit numunelerde olduğu sürelerde sinterleme işlemine tabi tutulmuştur. CNT nano takviye malzemelerinin kompozit yapı üzerindeki tesirini daha iyi değerlendirebilmek amacıyla takviyesiz \%100 ZA-27 malzemeden oluşturulmuş numuneye ait SEM görüntüsü ve tane sınırlarının daha belirgin göründüğü Back-Scattered-Electron (BSE) görüntüleri Şekil 3'te verilmiştir.
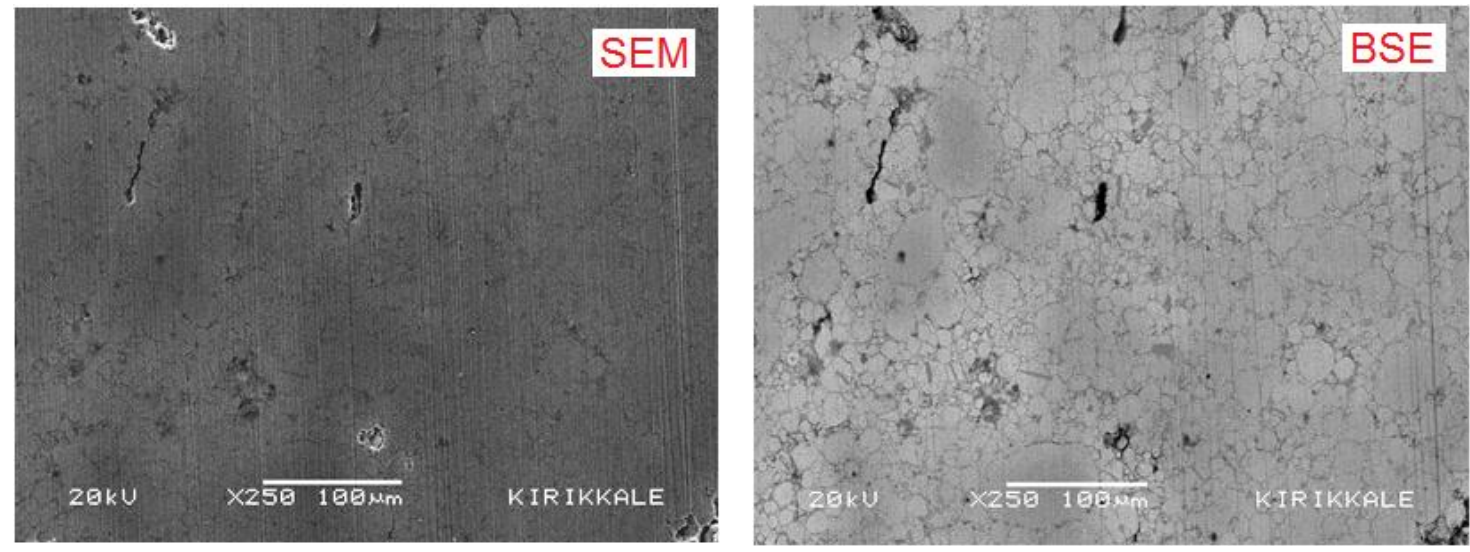

Şekil 3. Nano takviyesiz \%100 ZA-27, ×250 büyütmede mikroyapılar

Şekil 3'teki görüntüye bakıldığında yukarıda yapılan yorumları destekler nitelikte bir mikroyapı ile karşılaşılmaktadır. Kompozit karışımların hazırlanmasında uygulanan karıştırma yöntemi ve işlem parametrelerinin çok yeterli olamadığı ve azda olsa gözenek oluşumuna sebep olduğu söylenebilir. Ancak bu gözenek miktarı CNT nano malzeme takviyeli kompozit numuneler ile kıyaslanmayacak oranda düşüktür. Nano malzeme takviyesiz \%100 ZA-27 toz malzemeden oluşturulmuş numunenin mikrorapısı incelendiğinde toz metalurjisi yönteminden beklenen özellikte bir yapı meydana getirildiği söylenebilir. Ancak az miktarda da oluşan gözeneklerin bertaraf edilebilmesi ve daha mükemmel bir mikro yapıya ulaşmak için, toz metalurjisi işlemi önemli parametrelerinden olan sıkıştırma basıncı, ve sinterleme ısıl işlemininde ayrıca değerlendirilmesi uygun olacaktır.

Yukarıda yer alan nano malzeme takviyesiz ZA-27 numunenin mikroyapısına bakıldığında ve yapı içerisindeki gözenekler dikkate almadan değerlendirme yapıldığında, $400{ }^{\circ} \mathrm{C}$ 'lik sinterleme sıcaklığ 1 ve uygulanan 90 dakika sinterleme süresinin uygun olduğu söylenebilir. Zira SEM ve BSE görüntüsünden de anlaşılacağı üzere ZA-27 tanecikleri arasında beklene boyun ve bağ oluşumunun gerçekleştiği görünmektedir. Bu sonuçlara göre, nano malzeme katkılı kompozit numunelerin üretim parametreleri olarak seçilen $500 \mathrm{MPa}$ sıkıştırma basıncı, 90 dakika sinterleme süresi ve $400^{\circ} \mathrm{C}, 425{ }^{\circ} \mathrm{C}$ ve $450{ }^{\circ} \mathrm{C}$ sinterleme sıcaklıklarının gözden geçirilerek bundan sonraki çalışmalarda değerlendirilmesi tavsiye edilmektedir.

\subsection{Gözenekliliğin (Yoğunlukların) İncelenmesi}

Toz metalurjisi yöntemiyle üretilen CNT katkılı kompozitlerin Arşimet prensibi kullanılarak ölçülen gözenek oranlarını gösteren grafik Şekil 4'te verilmiştir. 


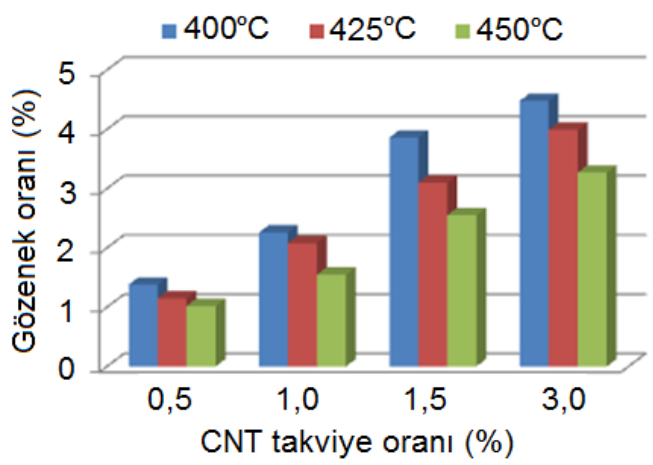

Şekil 4. CNT /ZA-27 kompozitlerin gözenek miktarları

Şekil 4'teki grafiklere bakıldığına ilk etapta nano CNT takviye oranlarının artışına bağlı olarak gözenek miktarlarının yükselmekte olduğu görünmektedir. Yapılan farklı çalışmalarda benzer sonuçlar ifade edilmiştir (Çelebi ve ark. 2015), (Dalmış ve ark. 2016), (Sayed ve ark. 2012), (Saheb ve ark. 2012). Takviye elemanının nano boyutta olması, karıștırma işleminde ZA-27 matris içerisine nano malzemelerin homojen olarak dağılımasını zorlaştırmıştır. Karıştırma işleminde kullanılan mekanik yöntemin çok küçük boyuttaki nano parçacıkların birbirinden ayrılarak matris malzemesi ZA-27 tozları içerisinde topaklanmadan ve homojen olarak dağılmasında yeterli olamamıştır. CNT takviye oranlarının artmasıyla bu durum daha da zorlaşarak kompozit yapı içerisindeki gözeneklilik miktarlarını arttırmışıı. Benzer sonuçlar literatürde yer almıştır (Zhou ve ark. 2017) (Şenel ve ark. 2017). Ayrıca Şekil 2 (a), (b), (c), (d)'de verilen mikroyapı görüntülerine bakıldığında takviye oranı ile gözeneklilik arasındaki ilişki açık olarak gözlenebilmektedir.

İkinci genel durum ise, tüm takviye oranlarında sinterleme sıcaklığının artmasıyla porozite oranlarının önemli ölçüde düşme eğilimidir. Sinter sıcaklığının yükselmesi kompozit yapının yoğunluğu arttırarak gözene miktarının azalmasına katkı sağlamıştır. Literatürde benzer bir sonuç yer almaktadır (Islak ve ark. 2014), (Garg ve ark. 2016), (Saheb ve ark. 2012). Bu malzeme davranışı beklenen bir durum olmakla birlikte, özellikle sinterleme sıcaklığının $425^{\circ} \mathrm{C}$ 'den $450^{\circ} \mathrm{C}$ ye çıkmasıyla porozite değerlerindeki azalma, $400^{\circ} \mathrm{C}^{\prime}$ den $425^{\circ} \mathrm{C}^{\prime}$ ye çıkmasından daha etkili olmuştur. $\mathrm{Bu}$ sonuca göre sinterleme sıcaklığ $425^{\circ} \mathrm{C}^{\prime}$ ye yükseldikten sonra, kompozit yapıda daha fazla değişime neden olmuştur. Sinterlemenin en önemli tesiri ZA-27 taneleri arasındaki boyun oluşumunu arttırması ve taneler arası bağlanmayı sağlamasıdır. Yapılan yoğunluk ölçümü ve gözeneklilik hesaplamalarına göre; en düşük porozite değeri $450^{\circ} \mathrm{C}$ 'de sinterlenmiş $\% 0,5$ nano $\mathrm{CNT}$ takviyeli kompozitten, en yüksek porozite değeri ise $400^{\circ} \mathrm{C}$ 'de sinterlenmiş $\% 3,0$ nano CNT takviyeli kompoziten elde edilmiştir.

\subsection{CNT Takviye Oranına Göre Mikroyapıların Değerlendirilmesi}

CNT nano malzeme oranlarının kompozit yapı içerisindeki durumunu incelemek amacıyla $\% 0,5-\% 1,0-\% 1,5$ ve $\% 3,0$ oranlarında CNT takviyeli ve $450^{\circ} \mathrm{C}$ 'de sinterlenmiş kompozit malzemelerin BSE görüntüleri Şekil 5 'te verilmiştir.
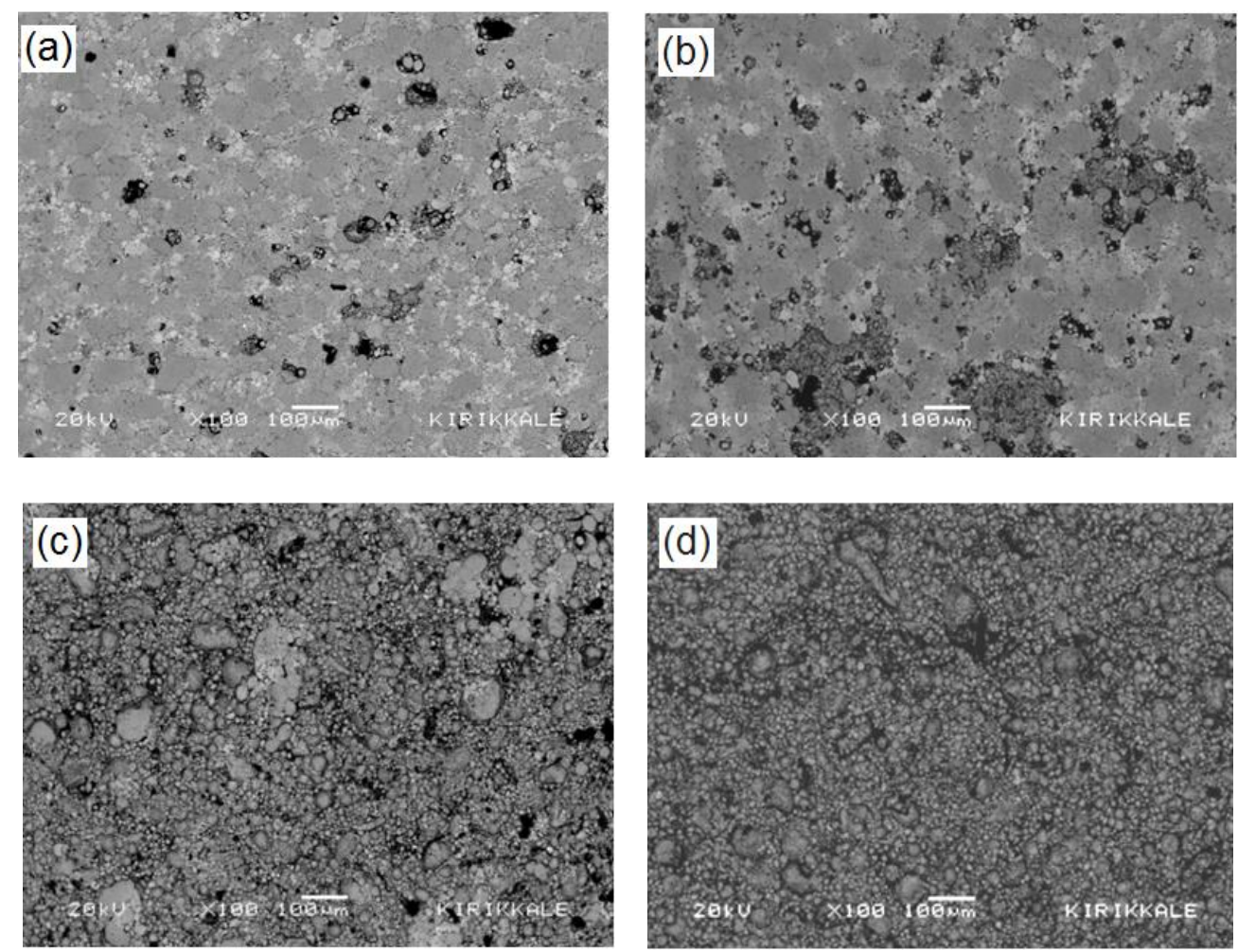

Şekil 5. $450^{\circ} \mathrm{C}^{\prime}$ de sinterlenmiş, $\% 0,5$ (a), \%1,0 (b), \%1,5 (c) ve \%3,0 (d) CNT takviyeli kompozit malzemelerin $\times 100$ büyütmede BSE görüntüleri 
Şekil 5'teki görüntüler incelendiğinde, CNT takviye miktarının artışına bağlı olarak kompozit yapı içerisindeki gözenekliliğin artmakta olduğu çok açıkça görünmektedir. Şekil 5 (a) ile Şekil 5 (d) arasındaki mikroyapısal farklılıktan da anlaşılacağı üzere, CNT miktarının artmasıyla birlikte ZA-27 matris malzemesi taneciklerinin birbiriyle bağ oluşumu giderek zayıflamıştır. BSE görüntülerindeki koyu renkteki bölgeler kompozit yapı içerisindeki gözenekli (boşluklu) bölgeleri ifade etmektedir. Şekil 5'teki görüntülere bakıldığında CNT takviye oranının \% 0,5 ’ten yukarıya doğru çıkmasıyla kompozit yapı içerisindeki gözenekli bölgelerinde artmakta olduğu anlaşılmaktadır. CNT nano malzemeler ZA-27 matris malzemesinin arasına yerleşerek matris malzemesinin sinterlemede arzu edilen taneler arası boyun ve bağ oluşumunu olumsuz etkilemiştir. CNT takviye malzemesinin sahip olduğu çok yüksek yüzey alanı değerlerinin $\left(C N T=240 \mathrm{~m}^{2} / \mathrm{g}\right)$ ve yüzey enerjisinin sinterleme sırasında etkili olduğu ve adeta ZA-27 tanecikleri arasında bir ara yüzey oluşturarak 1sı transferini azaltmış olabileceği değerlendirilmektedir.

\subsection{Sinterleme Sıcaklıklarına Göre Mikroyapıların Değerlendirilmesi}

Mikroyapıların sinterleme sıcaklıklarına göre değerlendirmesine geçilmeden önce bu deneysel çalışmaya özgü özel bir durumu açıklamak uygun olacaktır. Bu çalışma literatürde az rastlanan bir sonuç ortaya koymaktadır. Matris malzemesi olan ZA-27 çinko-alüminyum alaşımının erime derecesi $484^{\circ} \mathrm{C}$ 'dir. Toz metalurjisi ile elde edilen kompozitlerin sinterleme işlemine ilk olarak $400^{\circ} \mathrm{C}$ ile başlanmış ancak beklenen yapı elde edilememiştir. Daha sonra $425^{\circ} \mathrm{C}$ 'ye çıkılarak sinterleme yapılmış olmasına rağmen yine beklenen taneler arası bağlanma meydana gelememiştir. Son olarak $450^{\circ} \mathrm{C}$ sicaklıkta sinterleme yapılarak çalışma tamamlanmıştır. Normal şartlarda, çıkılan bu sinterleme sıcaklıklarında ana malzeme olan ZA-27'nin yumuşayarak kompozit numunelerin deforme olması beklenirken böyle olmamıştır. Bu beklenmeyen malzeme davranışının, kompozit yapı içerisine katkılanan CNT takviye elemanıyla ilişkili olduğu düşünülmektedir. Sinterleme sırasında ısıl işlem fırını içerisindeki sıcaklığın tamamının matris malzemesine etki yapamayıp, ısının bir kısmının nano CNT takviye malzemesi tarafından absorbe edildiği varsayılmıştır. Bu durum teknik olarak, kullanılan nano malzemenin sahip olduğu çok yüksek spesifik yüzey alanı değerlerine atfedilmiştir. Yukarıdaki açıklama ve değerlendirmelerden sonra; seçilen takviye oranları içerisinde orta değer olan \% $1,5 \mathrm{CNT}$ takviyeli ZA-27 matrisli kompozitlerin, sinterleme sicaklıklarına göre mikroyapılarını değerlendirmek amacıyla yine tane sınırlarının daha belirgin göründüğ̈ BSE görüntüleri Şekil 6'da verilmiştir.
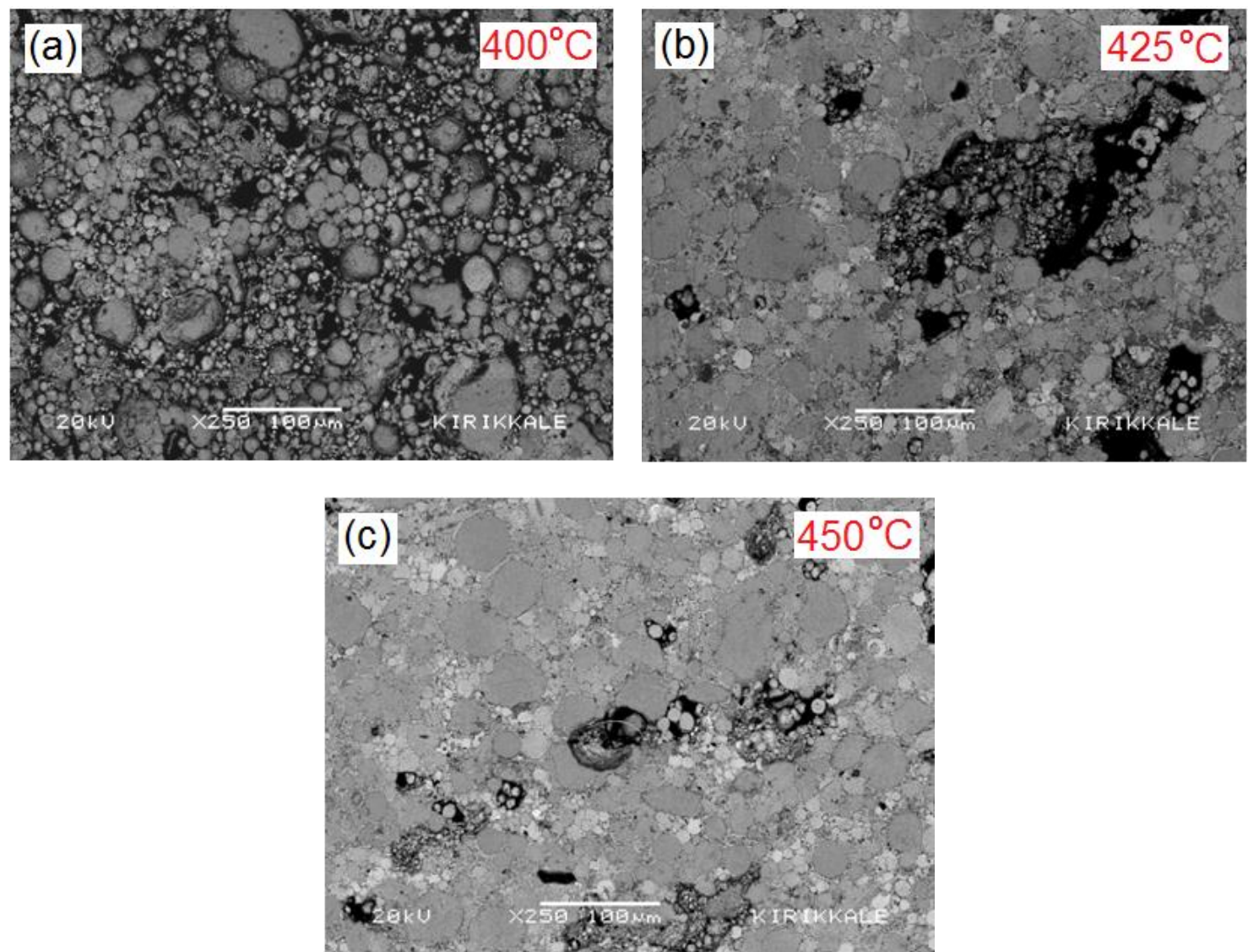

Şekil 6. \% 1,5 CNT takviyeli nano kompozitlerin sinterleme sıcaklıklarına göre $\times 250$ büyütmede BSE görüntüleri

Şekil 6'daki BSE görüntüleri incelendiğinde, genel olarak sinterleme sıcaklığının artışına bağlı olarak ZA-27 tanecikleri arasındaki boyun oluşumunun arttığı söylenebilir. Sinterleme sıcaklığının artışı ZA-27 taneleri arasındaki bağlanmayı olumlu etkileyerek, kompozit yapıdaki matris malzemesi ZA-27 üzerindeki gözenek oranının da azalmasına neden olmuştur. Şekil 6'daki (a), (b) ve (c) görüntülerine bakıldığında kompozit yapının giderek sıkılaştığı görünmektedir. Ancak malzeme topaklanmasının olduğu gözenekli bölgelerde sinterleme sıcaklık artışının çok etkili olamadığı söylenebilir. Topaklanmanın oluştuğu bölgelerdeki ZA-27 parçacıklarının çevresinde ve yüzeylerinde yoğun olarak nano takviye elemanlarının bulunduğu ve sinterleme sıcaklıklarının matris malzemesi ZA-27 içerisine tesir edemediği varsayılmaktadır. Diğer taraftan Şekil 6 (c) incelendiğinde, özellikle $450^{\circ} \mathrm{C}$ 'de sinterlenmiş kompozit yapıdaki taneler arası bağlanmanın iyi olduğu, ZA-27 tanecikleri arasındaki ara yüzey sınır çizgilerinden anlaşılmaktadır. Bu durumda sinterleme sıcaklık artışının kompozit yapıyı olumlu 
etkilemiş olduğu sonucuna varılabilir. Yapılan bu değerlendirmelerden sonra kompozit yapı içerisindeki nano malzemenin incelenebilmesi amacıyla en düşük $(\% 0,5)$ ve en yüksek $(\% 3,0)$ takviye oranına ait CNT katkılı kompozit numunelerden $\times 20000$ büyütmede çekilen SEM görüntüleri Şekil 7'de verilmiştir.

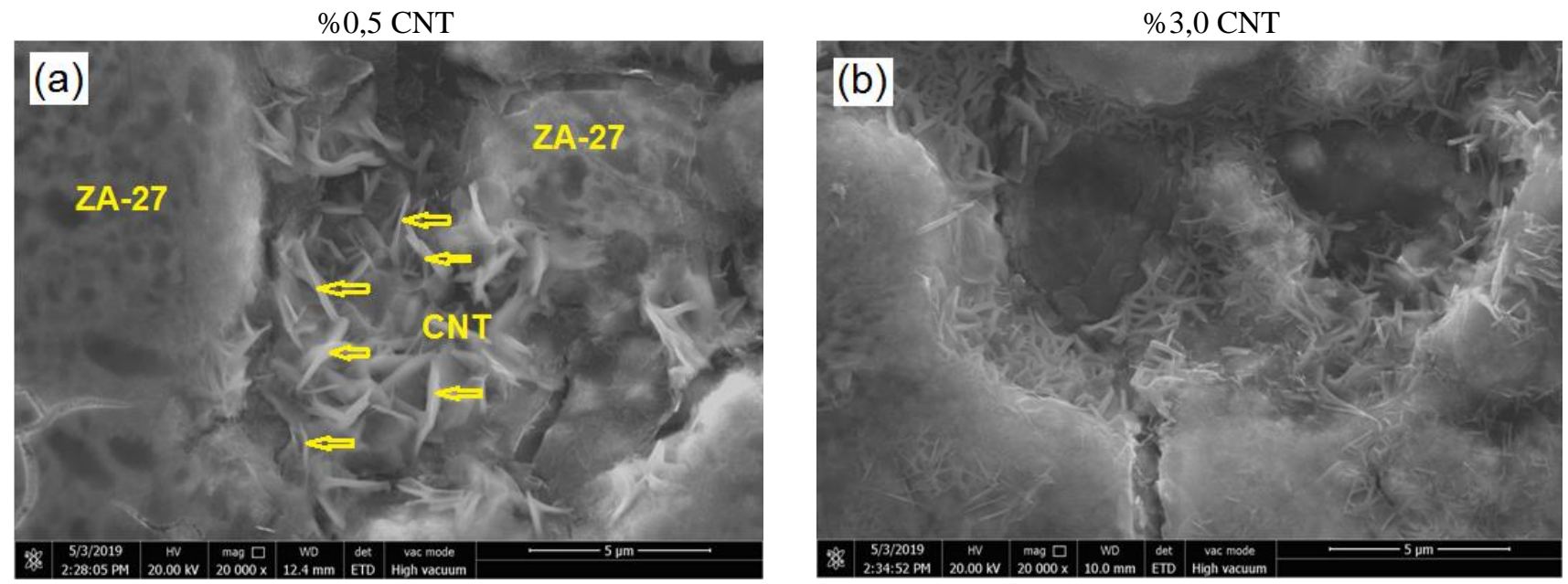

Şekil 7. Nano boyutta CNT malzemelerin göründüğü mikroyapılar

Şekil 7'deki SEM görüntüleri incelendiğinde kompozit yapılar içerisinde CNT nano malzemeler rahatlıkla seçilebilmektedir. Özellikle Şekil 7 (b)'deki \%3,0 CNT katkılı numuneye ait SEM görüntüsü dikkati incelendiğinde CNT takviye malzemesinin ZA-27 tanecikleri üzerinde yoğun olarak yer aldığı ve matris malzemesi ZA-27'yi tamamen kapladığ görünmektedir. Daha önce yapılan yorumlarda da ifade edildiği üzere nano malzemenin yüksek oranda yer aldığı numunelerde ZA-27 tanecikleri arasındaki bağ oluşumunun zayıfladığı anlaşılmaktadır. ZA-27 tanecikleri üzerinde yer alan ve tanecik yüzeyinin bir bölümünü kaplayan CNT partiküllerinin 1sı iletiminin zayıflamasına neden olduğu ve böylece ZA-27 taneleri arasında sinterleme sıcaklığının etkisinin azalarak taneler arası bağlanmanın olumsuz etkilendiği varsayılmıştır.

\subsection{Sertlik Ölçümlerinin Değerlendirilmesi}

Nano katkılı ZA-27 kompozitlerin sertlik ölçümleri Brinell yöntemi kullanılarak, 15,625 kg yükleme ile 2,5 mm'lik ölçme probuyla cihazda yapılmıştır. CNT nano malzeme katkılı kompozitlerin sertlik ölçme sonuçlarından hesaplanan ortalama değerlere göre çizilen grafikler Şekil 8'de verilmektedir.

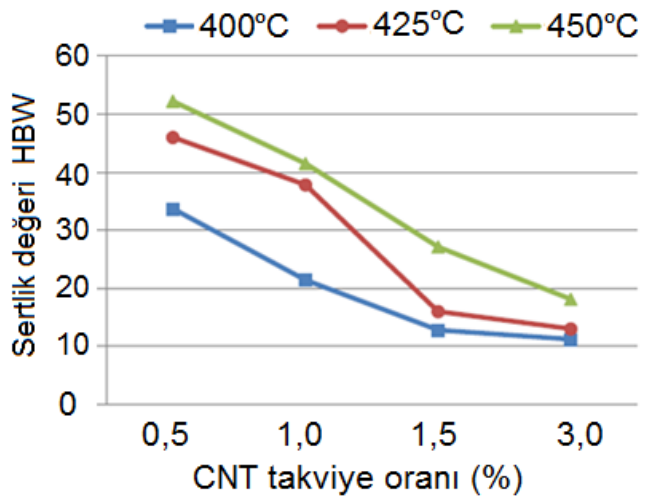

Şekil 8. CNT takviyeli ZA-27 nano kompozitlerin CNT oranına göre sertlik değerleri

Şekil 8'deki grafiklere bakıldığında CNT takviye oranının artmasıyla sertlik değerlerinin önemli ölçüde düştüğü genel eğilim olarak görünmektedir. Bu durum üç farklı sinterleme sıcaklığı için de geçerlidir. Katkısız saf \%100 ZA-27 alaşımının setlik değerleri 53-56 HBW arasında değişirken, kompozit numunelerde ölçülen en düşük sertlik değeri $11,2 \mathrm{HBW}$ ile $400^{\circ} \mathrm{C}$ de sinterlenmiş \%3,0 CNT katkılı numunede, en yüksek sertlik değeri ise, $450^{\circ} \mathrm{C}$ de sinterlenmiş $\% 0,5$ CNT katkılı numunede 52,2 HBW olarak ölçülmüştür. En düşük sertlik değerini dikkate aldığımızda, bu değer matris malzemesi ZA-27 alaşımının beşte birine tekabül etmektedir. CNT nano malzeme katkısı kompozit yapının sertlik değerini çok yüksek oranda düşürmüştür.

Özellikle \%1,0 ve daha yüksek oranlardaki $(\% 1,5$ - \%3,0) nano katkının sertlik değerlerini önemli ölçüde düşürdüğü görünmektedir. Nano takviye oranının \%1,5 civarına çıkmasıyla katkısız ZA-27 malzemeyle arasında yarıya yakın sertlik değeri düşmesi meydana gelmiştir. Nano katkının \%3,0 olduğu numunelerde sertlik ölçümleri sırasında bazı numunelerin dağılma eğilimi sergilediği ve sertlik ölçümünün çok zor yapılabildiği gözlenmiştir. Kompozit yapı içerisindeki nano katkılar ZA-27 matris malzemesi partiküllerinin birbiriyle bağ yapmasını önemi ölçüde engellemiş olduğu söylenebilir. Sinterleme sırasında meydana gelen ısının tamamının matris malzemesine etki yapamayıp nano takviye malzemeleri tarafından absorbe edilmiş olduğu değerlendirilmektedir. Bu duruma en önemli etkiyi, nano malzemelerin çok yüksek spesifik yüzey alanına sahip olmasının neden olduğu sanılmaktadır. Sinterleme sıcaklık değişimlerinin kompozit yapının sertliğine etkisini değerlendirmeye devam etmek amacıyla çizilen farklı bir grafik Şekil 9' da verilmiştir. 


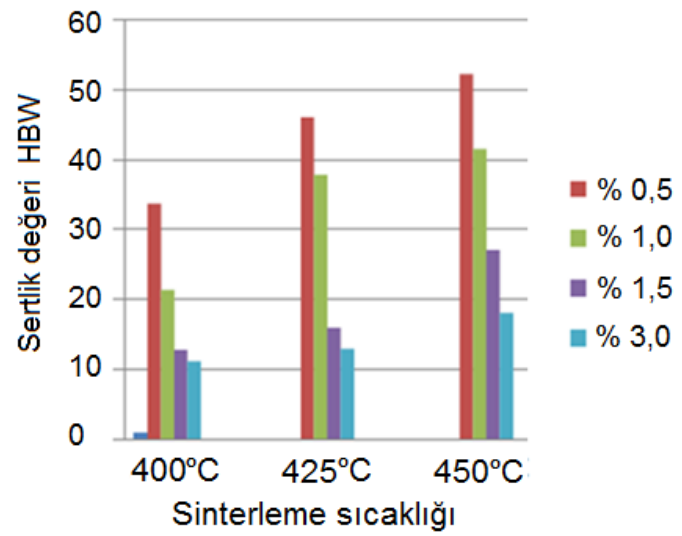

Şekil 9. CNT takviyeli ZA-27 nano kompozitlerin sinterleme sıcaklıklarına göre sertlik değerleri

Şekil 9'daki grafiklere bakıldığında; sinterleme sıcaklı̆̆ının artmasıyla sertlik değerlerinin yükselme eğilimi gösterdiği ifade edilebilir. Bu durum tüm takviye oranlarında geçerlidir. Sinterleme sıcaklığının artmasıyla ZA-27 tozları arasındaki bağlanma olumlu yönde etkilenmiştir. Bütün takviye oranlarında en düşük sertlik değerleri $400^{\circ} \mathrm{C}$ de sinterlenmiş numunelerden elde edilirken, en yüksek sertlik değerleri $450^{\circ} \mathrm{C}$ de sinterlenmiş nano kompozit numunelerden elde edilmiștir. Normal şartlarda ZA27 alaşımının erime derecesi $419-484^{\circ} \mathrm{C}$ aralı̆̆ındadır. Ancak deneysel çalışmanın ön denemelerinde $400^{\circ} \mathrm{C}$ sinterleme sıcaklığı kullanılarak numunenin yapısı kontrol edildiğinde sinterleme işleminden beklenen tanecik bağlanmasının oluşmadığı ve kompozit numunenin en ufak bir dış etki ile dağılma eğiliminde olduğu gözlenmiştir. Daha sonra $425^{\circ} \mathrm{C}$ ile tekrar sinterleme işlemleri yapılmış ancak yine aynı şekilde taneler arasında istenilen sağlam bağ yapısı elde edilememiştir. Bu denemelerden sonra sıcaklık $450^{\circ} \mathrm{C}$ ye çıkarılmıştır. Kompozit numunelerin yapısında yüksek oranda ZA-27 alaşımı bulunduğundan, doğal olarak sinterleme işlemi sırasında kompozit yapı içerisindeki ZA-27 malzemenin erime eğilimi göstermesi ve deformasyona uğraması beklenirken böyle olmamıştır. Sinterleme sırasında meydana gelen ısının bir kısmı nano takviye malzemeleri tarafından absorbe edilmiş olduğu daha önce ifade edilmiştir. Bu literatürde pek rastlanmayan sonuç, kompozit yapı içerisindeki CNT nano katkıların çok yüksek yüzey enerjisi ve çok geniş spesifik yüzey alanına atfedilmiştir.

\section{6. Üç Nokta Ĕ̆me (Çapraz Kırılma) Deney Sonuçlarının Değerlendirilmesi}

Üç nokta eğme deneyleri 5 ton kapasiteli üç nokta eğme deney presinde $50 \mathrm{~N} / \mathrm{s}$ deney yükü uygulanarak yapılmıştır. Eğme deneylerinden elde edilen kırılma yükü değerleri Şekil 10'daki grafikte verilmiştir.

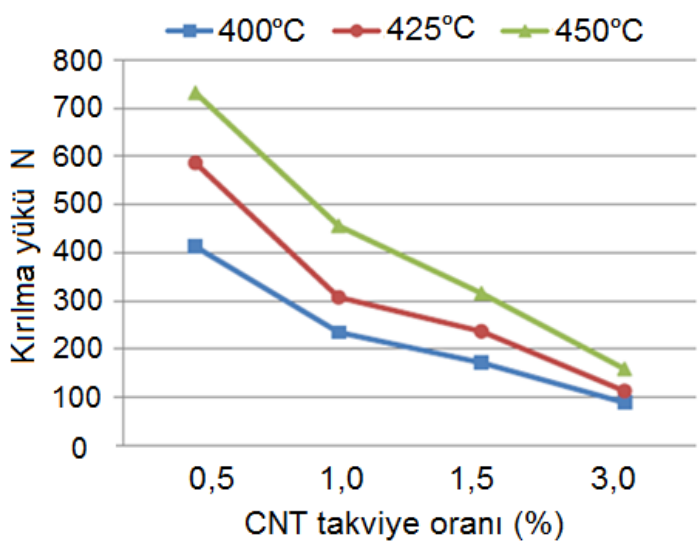

Şekil 10. CNT takviyeli ZA-27 nano kompozitlerin kırılma yükü değerleri

Şekil 10'daki grafikler incelendiğinde, ilk göze çarpan kompozit yapı içerisindeki CNT takviye oranının artı̧ıyla birlikte kırılma yükü değerlerindeki azalmadır. Diğer önemli husus ise sinterleme sıcaklığının artmasıyla bütün takviye oranlarında kırılma yükü değerlerinin de artı̧̧ göstermesidir. En yüksek kırılma yükü değeri, $450^{\circ} \mathrm{C}$ de sinterlemiş $\% 0,5 \mathrm{CNT}$ takviyeli kompozit numunede $732 \mathrm{~N}$ olarak ölçülürken, en düşük değer $400^{\circ} \mathrm{C}$ de sinterlenmiş $\% 3,0 \mathrm{CNT}$ takviyeli kompozit numunede $92 \mathrm{~N}$ olarak kaydedilmiştir. Bu iki değer arasında yaklaşık 8,5 kat fark bulunmaktadır. Aynı şekilde bu iki değerin ölçüldüğü takviye oranları arasında da 8 kat fark vardır. Buradan çıkaracağımız sonuç, takviye artış oranı ile kırılma yükü değeri arasındaki ters orantıdır. Diğer taraftan kırılma değerlerini sertlik değerleriyle birlikte ele aldığımızda aralarında doğru orantı olduğunu söyleyebiliriz. Sertlik değeri düşük olan yüksek oranda CNT takviyeli numuneler aynı zamanda da düşük kırılma direnci sergilemiştir. Yani takviye oranlarının yükselmesi hem sertlik hem de kırılma yükü değerlerinin düşmesine sebep olmuştur. Yapılan deney ve ölçümler değerlendirildiğinde, takviye oranı ne kadar arttırılırsa kırılma yükü değerinin de o oranda azalacağı sonucu ortaya çıkmıştır. Kırılma yükü değerlerini sinterleme sıcaklıklarıyla birlikte değerlendirmek amacıyla Şekil 11'deki grafik oluşturulmuştur. 


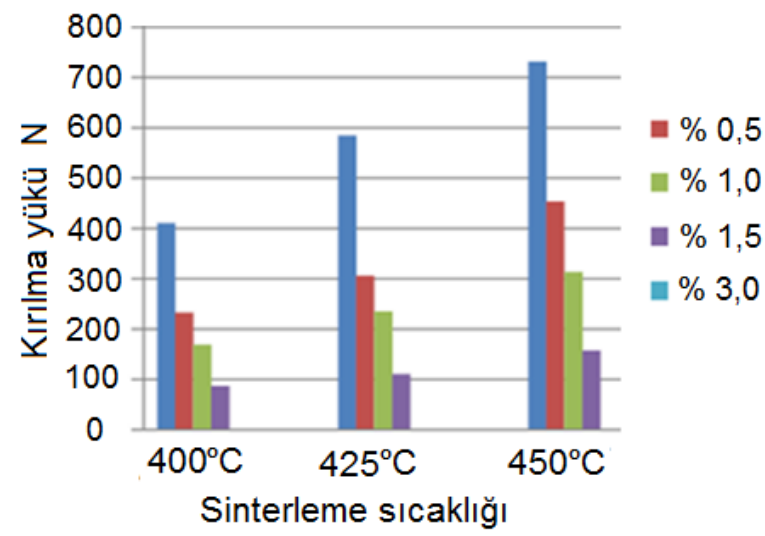

Şekil 11. CNT takviyeli ZA-27 nano kompozitlerin sinterleme sıcaklıklarına göre kırılma yükü değerleri

Şekil 23'deki grafiklere toplu olarak bakıldığında, sinterleme sıcaklığının artışıyla bütün takviye oranlarında ve her iki nano takviye malzemesinin kullanıldığı kompozit numunelerde kırılma yükü değerlerinin artış gösterdiği göze çarpmaktadır. Sinterleme sıcaklığının artmasıyla matris malzemesi olan ZA-27 tozlarının arasındaki boyun ve bağ oluşumu olumlu etkilenmiş ve kompozit yapının dayanımı miktar artmıştır. $400^{\circ} \mathrm{C}$ ila $450^{\circ} \mathrm{C}$ arasında $\% 10$ luk bir değer artışına karşın kırılma yükü değerlerinde ortalama \%45 artış gözlenmiştir. Sinterleme sıcaklık artışının nano kompozitlerin kırılmaya karşı direncini önemli ölçüde arttırdığı değerlendirilmiştir. Ayrıca kompozit numunelerin kırılma davranışlarına sinterleme sıcaklığının etkisini incelemek amacıyla, $400^{\circ} \mathrm{C}$ ve $450^{\circ} \mathrm{C}$ de sinterlenmiş, $\% 1,5 \mathrm{CNT}$ takviyeli kompozit numunelerin kırık yüzeylerinden $\times 1000$ büyütmede çekilen SEM görüntüleri Şekil 12’de verilmiştir.
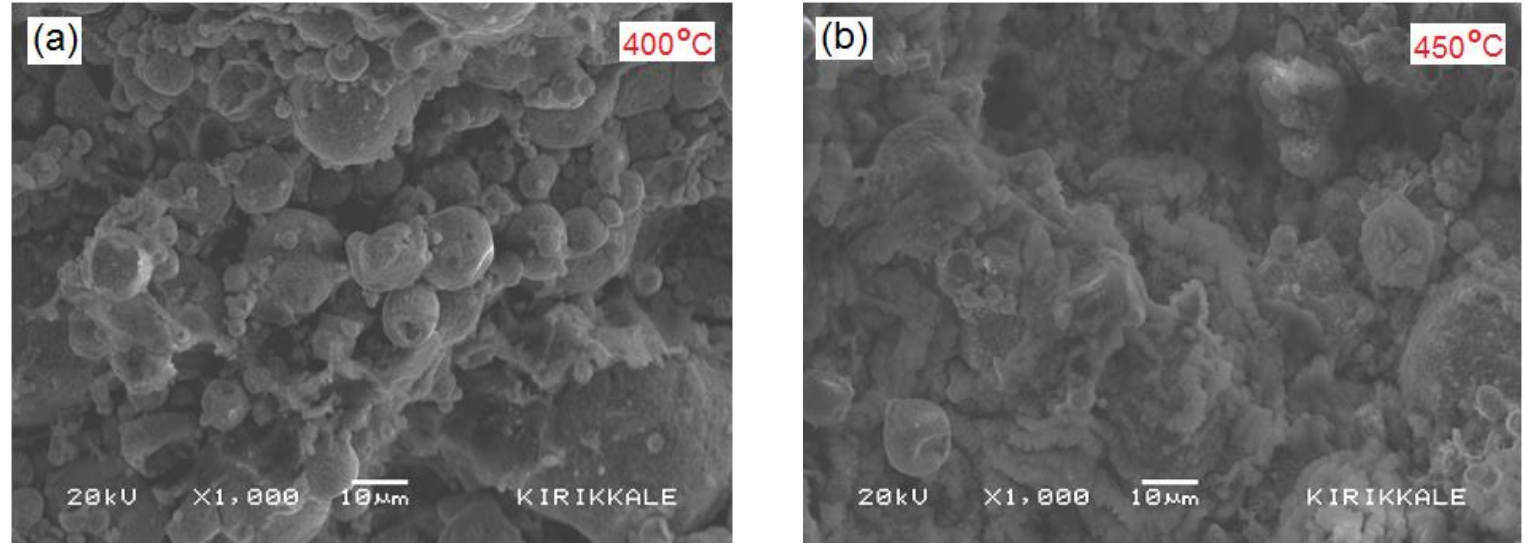

Şekil 12. $400^{\circ} \mathrm{C}$ ve $450^{\circ} \mathrm{C}$ de sinterlenmiş, $\% 1,5 \mathrm{CNT}$ takviyeli kompozit numunelerin kırık yüzey görüntüleri

Şekil 12'deki SEM görüntülerine genel olarak bakıldığında kırılmaların gevrek kırılma şeklinde olduğu görünmektedir. SEM görüntüleri dikkatle incelendiğinde; kompozit numunelerin kırılmış bölgelerinde plastik deformasyonun meydana gelmediği ve kırılmanın genellikle yapı içerisindeki taneler arasındaki kopmalardan oluştuğu görünmektedir. Buna göre kırılmaların gevrek kırılma mekanizması şeklinde gerçekleştiği ifade edilebilir. Ayrıca bazı ZA-27 taneciklerinin yapı içerisinden koparak düştüğü ve yerinde boşluk meydana geldiği SEM görüntülerinden anlaşılmaktadır. Sinterleme sıcaklığının kırılma üzerindeki etkisini değerlendirecek olursak; $400^{\circ} \mathrm{C}$ ve $450^{\circ} \mathrm{C}$ de sinterlenmiş CNT takviyeli kompozit numunelerin kırılmış yüzeyleri arasındaki fark açıkça görünmektedir. $400^{\circ} \mathrm{C}$ 'de sinterlenmiş CNT takviyeli kompozit numunenin kırık yüzeyindeki ZA-27 tanecikleri birbirinden bağımsız ve genellikle aralarında bağ ve boyun oluşturmamış şekilde yer almaktadır Şekil 12 (a). $450^{\circ} \mathrm{C}^{\prime}$ de sinterlenmiş CNT takviyeli kompozit numunede ise durum biraz daha farklı görünmektedir. ZA-27 toz tanecikleri arasında tam olmasa da bağ ve boyun oluşumunun gerçekleştiği Şekil 12 (b)'deki mikroyapı görüntüsünden anlaşılmaktadır. Ayrıca sinterleme sıcaklığının artmasıyla yapı içerisindeki taneler arası bağ ve boyun oluşumunun tesiri ile gözenekliliğin de bir miktar azaldığı ifade edilebilir.

\section{Sonuçlar}

Yapılan deneysel çalışmadan elde edilen sonuçlar aşağıda sıralanmıştır:

-Toz metalurjisi yöntemi kullanılarak elde edilen karbon nanotüp (CNT) malzemesi ile takviye edilmiş kompozitlerde arzu edilen yapısal homojenliğe ulaşılamamıştır.

-Kompozit yapılar yer yer yoğun gözeneklilik ile birlikte topaklanma eğilimi sergilemiştir. Bu tür nano malzeme katkı metal matris kompozitlerinin üretiminde farklı kompozit üretim yöntemleri kullanılarak elde edilen sonuçların karşılaştırılması önerilmektedir. 
- Kompozit yapıya eklenen CNT takviye elemanı, kompozit yapıların yoğunluğunun azalmasına neden olduğu sonucuna varılmıştır. Dolayısıyla CNT takviye elemanı oranı \% 0,5’ten \% 1,0,\% 1,5 ve \% 3,0'e yükseldiğinde, gözenekli yapı kompozit numunelerin mekanik davranışını çok daha olumsuz bir şekilde etkilemiştir.

- Kompozit yapıdaki CNT takviye elemanı miktarındaki artıştan dolayı, kompozit malzemelerin sertlik değerleri ve çapraz kırılma dayanımları önemli ölçüde azalmıştır. Bununla birlikte, sinterleme sıcaklığının arttırılmasıyla sertlik değerleri ve çapraz kırılma dayanımı değerleri kendi içinde artış göstermiştir.

- Kompozit yapıya dahil edilmiş CNT nano takviye elemanı, sinterleme ısıl işlemi sırasında sıcaklığın bir bölümünü absorbe ederek kompozit yapının ve ZA-27 matris malzemesinin sıcaklık direncini arttırmıştır. Bu durum CNT takviye elemanının sahip olduğu oldukça geniş spesifik yüzey alanına atfedilmiştir.

- Genel bir sonuç olarak; CNT takviyesinin ZA-27 matrisli kompozitlerin mekanik dayanımını azalttığı, ancak sinterlemede uygulanan sıcaklıktaki artışın kendi içerisinde mekanik dayanımı artırdığı sonucuna varılmıştır.

\section{Teşekkür}

Bu çalışma 2018/043 numaralı proje kapsamında Kırıkkale Üniversitesi BAP Birimi tarafından desteklenmiştir.

\section{Referanslar}

ASTM-B 528-05. (2008). Standard Test Method for Transverse Rupture Strength of Metal Powder Specimens. ASTM International West Conshohocken, PA 19428-2959, United States.

Bakshi, S. R., Lahiri, D., Agarwal, A. (2010). Carbon nanotube reinforced metal matrix composites - A Review. International Materials Reviews, 55 (1), 41-61. doi:10.1179/095066009X12572530170543

Çelebi, M., Çuvalcı, H., Çanakçı, A., Güler O. (2015). Nano-Parçacık Takviyesinin Mekanik Alaşımlama Yöntemiyle Üretilen ZA-27/A12O3 Kompozitlerinin Mekanik Özelliklerine Etkisi. MYT-2015, Bayburt, 197-203.

Dalmis, R., Cuvalci, H., Canakci, A., Guler, O. (2016). Investigation of Graphite Nano Particle Addition on The Physical and Mechanical Properties Of ZA27 Composites. Advanced Composites Letters, 25 (2), 37-42. doi: 10.1177/096369351602500202

El-Sayed Sherif, M., Latief F.H., Junaedi H., Almajid A. A. (2012). Influence of Exfoliated Graphite Nanoplatelets Particles Additions and Sintering Temperature on the Mechanical Properties of Aluminum Matrix Composites. Int. J. Electrochem. Sci., 7 4352-4361.

Garg, P., Gupta, P., Kumar, D., Parkash, O., (2016). Structural and Mechanical Properties of Graphene reinforced Aluminum Matrix Composites. J. Mater. Environ. Sci. 7 (5), 1461-1473.

Islak, S., Kır, D., Buytoz, S. (2014). Effect of Sintering Temperature on Electrical and Microstructure Properties of Hot Pressed Cu-TiC Composites. Science of Sintering, 46, 15-21. doi: 10.2298/SOS1401015I

Pul, M. (2019). Karbon Nanotüp (CNT) Ve Nano Grafen (G) Takviyeli Al 2024 Kompozitlerin Vorteks Yöntemiyle Üretilerek Aşınma Ve İşlenebilme Özelliklerinin İncelenmesi. Uluslararası Mühendislik Araştırma ve Geliştirme Dergisi, 11 (1), $370-382$. doi:10.29137/umagd.493868

Saheb, N., Khalil, A., Hakeem, A., S., Laoui, T., Al-Aqeeli, N. (2012). Carbon Nanotube Reinforced Al6061 and Al2124 Nanocomposites. ECCM15 - 15th European Conference on Composite Materials, June 24 to 28, Venice, Italy.

Şenel, M. C., Gürbüz, M., Koç, E. (2017). Grafen takviyeli alüminyum esaslı kompozitlerin üretimi ve karakterizasyonu. Pamukkale University Journal of Engineering Sciences, 23( 8), 974-978. doi: 10.5505/pajes.2017.65902

Zhou, M., Qu, X., Ren, L., Fan, L., Zhang, Y., Guo, Y., Quan, G., Tang, Q., Liu, B., Sun, H. (2017). The Effects of Carbon Nanotubes on the Mechanical and Wear Properties of AZ31 Alloy. Materials, 10, 1385, 1-17. doi:10.3390/ma10121385 